\title{
In Search of Environmental-Oriented Campus: A Lesson from Managing Higher Education Institutions (Heis) Strategically and Profitably
}

\author{
Dedi Purwana ${ }^{1}$, Danesto Bacdayan Anacio $^{2}$ and Ari Warokka ${ }^{3}$ \\ ${ }^{1}$ Faculty of Economics - State University of Jakarta Indonesia, Indonesia \\ ${ }^{2}$ Center for Research - University of the Cordilleras, Philippines
}

${ }^{3}$ Othman Yeop Abdullah Graduate School of Business, Universiti Utara Malaysia, Malaysia

\begin{abstract}
The challenge of being the agent of change and main actor in supporting the environmentally sustainable development has put higher-education institutions (HEIs) in its strategic position to inspire and lead its stakeholders in implementing the environment-oriented economic and social growth. The role of higher-education institutions (HEIs) in promoting sustainable development (SD) is very important as HEIs are areas where learning is facilitated. In this relation, HEIs can promote SD through the integration of SD concepts in their curricula, as well as through the implementation of SD in various operations of those institutions. A latter case is analyzed, wherein the material recovery potential of three Philippine universities was determined. It was found that approximately $90 \%$ of solid wastes in faculty rooms in the three Philippine HEIs are potentially recoverable, as residual wastes only account for $6 \%-11 \%$. Furthermore, it is estimated that monetary returns from these recoverable materials range between the rates of P1.59 $(\$ .04)-\mathrm{P} 11.98(\$ .28)$ per day $(\$ 1.00=\mathrm{P} 43.00,2011)$. It is argued that HEIs of the Association of South East Asian Nations (ASEAN) may also have high material recovery potential, which can be validated through research as shown by the case of three campuses in the Philippines. The practice of HEIs recovering marketable wastes are important to achieving goals of SD, and helping to create a cluster of sustainable and green ASEAN HEIs by 2015 and beyond.
\end{abstract}

Keywords: Green HEI, Waste Recovery, Sustainable Development, Waste Appraisal.

\section{Introduction}

Sustainable development (SD) concepts have been gathering much attention in the agendas of numerous international meetings since the Brundtland Commission's landmark report "Our Common Future" in the 1980s. Then in 1992, SD was the guiding framework for international cooperation at the Earth Summit in Rio de Janiero in Brazil. SD once again took center stage at the World Summit on Sustainable Development in 2002, which developed the 10-Year Framework of Programs on Sustainable
Consumption and Production (10 YFP). Most recently, a similar theme is set in the United Nation's (UN) Conference on Sustainable Development (Rio+20) also in Rio de Jeniero, in 2012, which is the creation of green economies in the context of sustainable development.

SD has been defined as "development that meets the needs of the present without compromising the ability of future generations to meet their own needs" (WCED, 1987). In one way or another, SD concepts have been adopted by organizations and businesses through 
various environmental management strategies and practices. These environmental management strategies may be innate in the organization's agenda, or may also be in compliance with national government laws, international policy initiatives or accrediting agencies (for example, ISO).

The role of education is crucial in furthering and implementing the principle of SD globally. One of the pioneer conferences establishing the connection between education and SD occurred in 1990 during the Talloires Declaration in France. Twenty-two (22) HEI presidents and chancellors were convened by Jean Mayer, Tufts University President, in Talloires, France, to create a document in guiding HEIs for a sustainable future ('Report and Declaration', 1990). In 2005, the Decade of Education for Sustainable Development (DESD) was declared by the UN until 2014 (UNESCO, 2005). In effect, the DESD aims to: "integrate the principles, values, and practices of sustainable development into all aspects of education and learning." This move is indeed an important event to solidify practicing SD, since SD cannot be achieved if people are not aware of the concept.

Educational institutions are key players as to the goals stated in the DESD, as these are the primary venues where learning is facilitated. Universities and other highereducation institutions (HEIs) particularly have a greater role in SD because students are being prepared to enter the labor market (OECD, 2007). Knowledge and skills possessed by future business leaders and entrepreneurs will be obtained in part during their time at these HEIs.

Aside from emphasis on HEIs as educators of SD for future generations, various operations in HEIs should also be analyzed in order to be sustainable in nature. Alshuwaikhat and Abubakar (2008) argue that colleges and universities operate similarly with other industries. Waste production in HEIs is analogous to the operation of business establishments and health care facilities wherein universityrelated activities, such as workshops and laboratory use, infrastructure maintenance and the utilization of energy and materials pose significant environmental impacts. In this aspect, HEIs must promote SD concepts in a two-pronged manner - HEIs should operate in a sustainable matter, at the same time, educating future generations about SD.

Among the various operations within the university where SD may be integrated is in solid waste management (SWM). Managing wastes have been discussed throughout the students' academic stages. Starting from the household, then primary and secondary schooling, and eventually higher education, concepts in SWM are discussed every now and then. In terms of SWM within the educational infrastructures, various waste bins may be present to encourage waste segregation among students and employees. However, such strategies, among other SWM operations within academic institutions, need comprehensive researches in order to analyze, improve and strengthen SWM practices.

Various waste assessment and characterization studies (WACS) in HEIs show that the majority of wastes produced in educational institutions are recoverable. In the following examples, around 45\%$86 \%$ of HEI wastes can be recovered. Brown University and University of Florida in the United States contain $45 \%$ and $53 \%$ of recyclable wastes respectively from their daily generated wastes (Brown University, 2004; UF Sustainability Task Force, 2002). The research of Smyth et al. (2010) determined that more than $70 \%$ of the weekly generated wastes in the Prince George campus of the University of Northern British Columbia (UNBC), Canada, could be diverted through reduction, recycling and composting schemes. In South America, particularly in Mexico, Armijo de Vega et al. (2008) discovered that $65 \%$ of one ton daily waste output taken from the Autonomous University of Baja California (UABC) at Mexicali campus could be recycled. Lastly, in Africa, Mbuligwe (2002) stated three HEIs in Tanzania; namely the University of Dar es Salaam (UDSM), the University College of Lands and Architectural Studies 
(UCLAS) and the Water Resources Institute (WRI) could reduce an average of $71-86 \%$ from routine generated wastes.

The high amount of recyclable or recoverable materials in HEIs indicates the inefficiency of waste management systems in these institutions to minimize serious environmental impacts brought upon by generated wastes. On the other hand, various opportunities are also present for HEIs to recover and capitalize on these recyclable wastes. This paper aims to present these opportunities, to minimize generated wastes, and at the same time to capitalize on recoverable materials present in the HEIs waste stream. Although a comprehensive analysis is further needed to identify data gaps, this paper illustrates the potential of HEIs in the Philippines to recover marketable wastes. In addition, lacking information regarding marketable wastes in ASEAN HEIs presents opportunities for researchers to identify strategies to market and minimize generated solid wastes in ASEAN colleges and universities, which will be shown in the case study of three Philippine HEIs.

\section{Methodology}

\section{Case Study of Material Recovery Potential of Three Philippine HEIS}

This paper presents results from an earlier waste assessment and characterization study (WACS) conducted by Anacio and Gomez (2011) from August to December 2010 in the faculty rooms and cafeterias of three HEIs in the Philippines, among a total of 2,080 HEIs (as of August 2010) present in the country ("Information on Higher Education System", 2011). Their research focused on universities in the Cordillera
Administrative Region (CAR) (see Fig. 1), particularly in Baguio City- a highly urbanized city in the Philippines.

There are currently 19 higher-education institutions in Baguio as of the $2^{\text {nd }}$ quarter of 2010. Eighteen (18) are privately owned while one, the University of the Philippines - Baguio campus, is managed by the national government (Commission on Higher Education - Cordillera Administrative Region [CHED-CAR], Regional Office, personal communication, July 2010).

The research focuses on the following private HEIs: Saint Louis University (SLU); University of the Cordilleras (UC) and University of Baguio (UB). These are the three biggest HEIs in Baguio City in terms of enrolment population, as well as the three current HEIs granted 'autonomous status' by CHED due to their excellent academic achievements. As of academic year 2009-2010, SLU, UC and UB have $31,370,18,833$ and 15,405 enrolled students, respectively. In addition, the three universities comprise almost $83.3 \%$ of the 78,784 students enrolled in the different colleges and universities of the City during the same year.

Furthermore, the results from the case study of the three HEIs shall be discussed in relation to HEIs in the Philippines and ASEAN in general. Due to the fact that various mechanisms are in place for a developed ASEAN in the future, most especially the concept of an ASEAN Community by 2015; this paper focuses on the importance of ASEAN HEIs, as sustainable industries and promoters of SD education, in order to achieve the goal of a sustainable ASEAN region beyond 2015. 


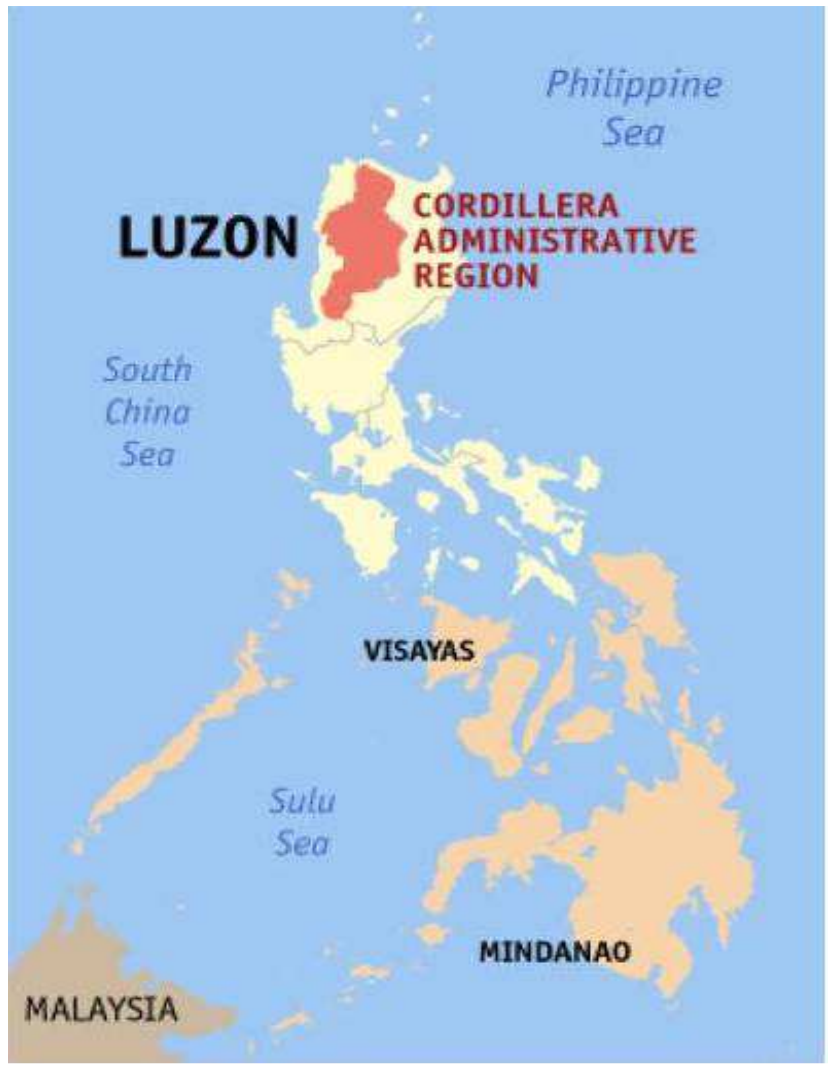

Figure 1. The Cordillera Administrative Region, Philippines (Where the Material Recovery Potential of Three HEIs were Analyzed)

\section{Results and Discussion}

\section{Material Recovery Potential of Faculty Rooms in the Three HEIs}

Material recovery potential in the faculty room for the three schools was determined as follows. In faculty rooms of SLU, $90 \%$ of the waste output by volume could be recovered. This accounts for $12 \%$ of paper wastes, $14 \%$ of plastic wastes, $2 \%$ of glasses, $17 \%$ of food wastes and $45 \%$ of biodegradable wastes. In faculty rooms of UB, $94 \%$ of the waste volume by weight can be recovered. This volume accounts for
$28 \%$ of biodegradable wastes, $27 \%$ of food wastes, $23 \%$ of plastics, $14 \%$ of paper wastes and $2 \%$ glass wastes. Finally, in UC, recoverable materials (by weight volume) include, respectively paper wastes, contributing 48\% (almost half of the waste stream by weight), biodegradable materials $20 \%$, plastic wastes $14 \%$, food wastes $7 \%$ and glass and textile wastes, with 1\%. Residual wastes (wastes which are destined for final disposal) in the three HEIs only account for $6 \%-11 \%$. A comparative interpretation can be seen in Table 1. 
Table 1. Waste Composition by Weight Volume of Faculty Room Wastes in the Three HEIs.

\begin{tabular}{|c|c|c|c|c|c|c|c|c|c|c|c|}
\hline & PAPERS & PLASTICS & METALS & GLASSES & FOOD WASTE & BIODEGRADABLE & TEXTILE & RUBBER & TETRA PAK & $\begin{array}{c}\text { RESIDUAL } \\
\text { WASTES }\end{array}$ & TOTAL \\
\hline SLU & $12 \%$ & $14 \%$ & $0 \%$ & $2 \%$ & $17 \%$ & $45 \%$ & $0 \%$ & $0 \%$ & $0 \%$ & $10 \%$ & $100 \%$ \\
\hline UB & $14 \%$ & $23 \%$ & $0 \%$ & $2 \%$ & $27 \%$ & $28 \%$ & $0 \%$ & $0 \%$ & $0 \%$ & $6 \%$ & $100 \%$ \\
\hline
\end{tabular}

\section{Opportunities for Marketing Recoverable Wastes in the Three Philippine Heis}

Aside from the high amount of recoverable wastes in the aforementioned HEIs, the recoverable materials have market values (Table 2). Monetary amounts derived from recoverable wastes in each $\mathrm{HEI}$ are as follows: $\$ 28 /$ day/faculty room in UC, $\$ .04 /$ day/faculty room in SLU and $\$ .04 /$ day/facultyroom in UB $(\$ 1.00=$ P43.00).

On a daily average, monetary returns from recoverable wastes in a faculty room in UC equal $\$ .28$ a day per faculty room. Paper and plastic wastes offer great avenues for monetary returns, wherein paper wastes (mainly white paper) in faculty rooms generate as much as $\$ .21$ per day, while plastics (mostly PET bottles) produce around $\$ .05$ a day. It is projected that a faculty room in UC could generate as much as $\$ 6.69$ in a single month (average of 24 school days for one month).

In UB, paper wastes profits $\$ .008$ per day, $\$ .02$ per day for plastic wastes, $\$ .003$ per day for glass wastes, $\$ .003$ per day for food wastes and $\$ .006$ per day for organic wastes, respectively. It is projected that a faculty room in UB could obtain $\$ .51$ in a single month (average of 24 school days for one month).

Finally, recoverable materials in SLU account for the following values: $\$ .01$ per day for paper wastes, $\$ .007$ per day for plastic wastes, $\$ .004$ per day for glass wastes and $\$ .003$ per day and $\$ .01$ per day for food wastes and organic wastes, respectively. Furthermore, it is projected that a faculty room could obtain $\$ .92$ in a single month (average of 24 school days for one month). 
Table 2. Estimated Market Values of Recoverable Materials as Of 2008 (NSWMC, 2009)

\begin{tabular}{|l|l|}
\hline \multicolumn{1}{|c|}{ Recyclable Item } & \multicolumn{1}{|c|}{$\begin{array}{c}\text { Estimated Factory Price (per kilo) [except ink } \\
\text { cartridges] }\end{array}$} \\
\hline Used white paper & $\$ 0.21$ \\
\hline Corrugated carton & $\$ 0.07$ \\
\hline Old newspaper & $\$ 0.14$ \\
\hline Assorted papers & $\$ 0.05$ \\
\hline $\begin{array}{l}\text { Polyethylene (PET) bottles w/o caps and } \\
\text { labels }\end{array}$ & $\$ 0.47$ \\
\hline PET bottles w/ caps and labels & $\$ 0.35$ \\
\hline High density polyethylene (HDPE) & $\$ 0.30$ \\
\hline Low density polyethylene (LDPE) & $\$ 0.23$ \\
\hline Printer casing plastics & $\$ 0.30$ \\
\hline Copper wire (reddish) & $\$ 8.14$ \\
\hline Copper wire (yellowish-red) & $\$ 13.04$ \\
\hline Copper wire (yellowish in thin strands) & $\$ 14.35$ \\
\hline Steel and Iron (ordinary) & $\$ .28$ to $\$ .33$ \\
\hline Stainless Steel & $\$ 1.63$ \\
\hline GI sheet & $\$ 0.23$ \\
\hline Tin can & $\$ 0.12$ \\
\hline Glass bottles & $\$ 0.01$ to $\$ 0.07$ \\
\hline Glass cullet & $\$ 0.12$ \\
\hline Ink cartridges & $\$ 2.33$ to $\$ 7.00$ (per piece in junk shops) \\
\hline Car battery & $\$ 0.27$ \\
\hline Note: $\$$ \$1.00 = P43.00) & \\
\hline
\end{tabular}

In addition, available markets are present in the Philippines for handling recoverable wastes. Around 70 recycling companies exist in the Philippines as identified by the NSWMC (2009). These companies handle plastic, paper, computer electronics, tin and other metals, glass, tetra pak, car batteries and rubber wastes. An illustrative map on the presence of such companies in the three general locations in the country is shown in Fig. 2. 


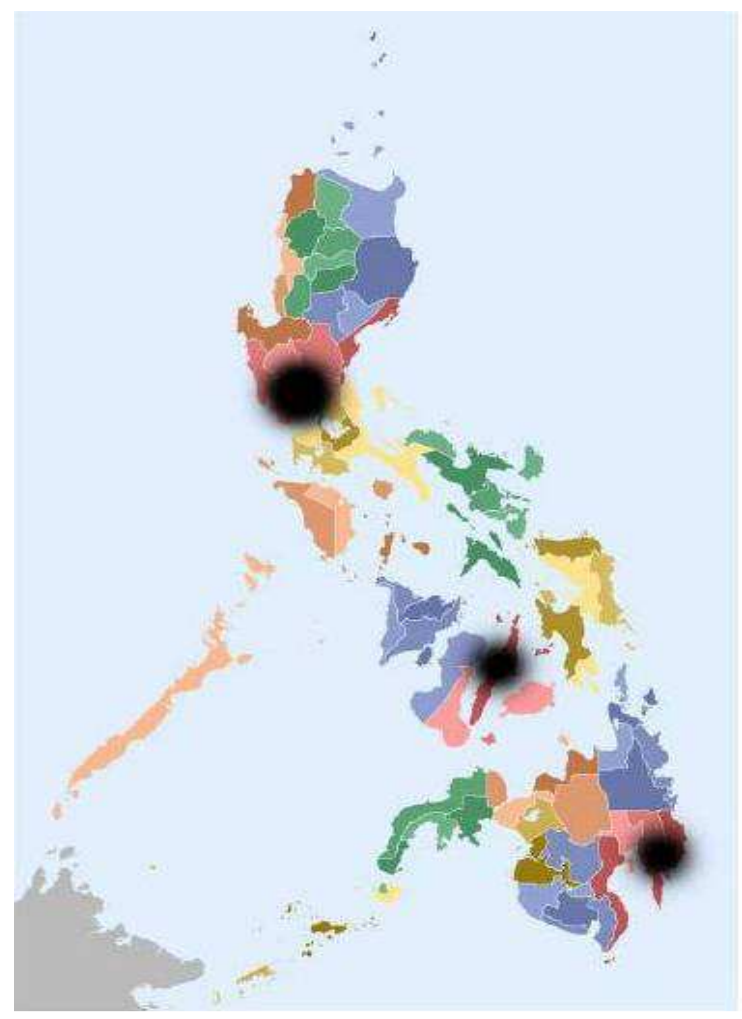

Figure 2. An Illustrative Map of the Location of Recycling Companies in the Philippines (Not To Scale).

\section{Implications for Heis in Philippines and ASEAN}

The three HEIs have a high potential for material recovery. As discussed previously, almost $90 \%$ of generated solid wastes in faculty rooms could have been recovered through waste reduction and minimization programs. These materials also have monetary values. Financial returns from marketing recoverable wastes could generate funds for various university activities and programs. Most importantly, the markets necessary for these recoverable materials are present in the Philippines as a number of recycling companies are currently in operation.

HEIs in other ASEAN countries may have a better advantage for marketing their recoverable wastes. For example, Cimelia Resource Recovery is said to operate Singapore's largest e-waste recycling and refinement plant. Its facilities span around $2,000 \mathrm{~m}^{2}$, and are capable of processing 25,000 metric tons of electronic refuse annually. Aside from Singapore, Cimelia
Resource Recovery also operates a plant in Bangkok, Thailand. A recycling company based in Malaysia, the Global E-Waste, purchases and remarkets unwanted electronic equipment (Algie, 2010). Tetra Pak is yet another company in operation in different ASEAN countries which recycle their food packaging products. These and other related companies in ASEAN not only allow HEIs to market their recoverable materials, but may also be the HEIs' partner for recycling initiatives.

Another aspect resulting from this paper would refer to ASEAN HEIs deriving income from waste marketing. Furthermore, recoverable wastes in HEIs may not only be marketed nationally, but internationally as well. It is projected that cross-border market for recyclable materials in Asia will expand. The crossborder movement of recyclable materials in Asia, including ASEAN, presents opportunities to develop a sound materialcycle society in the region (Hashi and Mori, 2005). As the year 2015 approaches, possibilities may exist for HEIs to market 
their recoverable materials nationally, and also to their ASEAN neighbors. The possibility of ASEAN HEIs recovering and marketing recyclable materials is very high, as shown in the abovementioned Philippine case.

In relation to HEIs in ASEAN marketing, their recoverable waste is an ambitious plan set to be in motion by the year 2015 . As a result of the $14^{\text {th }}$ ASEAN Summit in Thailand in 2009, a higher-education cluster involving 6500 HEIs and 12 million students in ten countries of ASEAN by the year 2015 is planned (Iskandar, n.d, ASEAN Secretariat, 2009).

Because this paper has only presented a case in the Philippines, the body of knowledge concerning the material recovery potential and markets in ASEAN is not very comprehensive. Various factors concerning solid wastes in HEIs still need consideration and analysis. The concept of building a database of related researches regarding this aspect not only important for documentation purposes, but also for identifying practices that can help HEIs improve waste recovery and its marketing systems. Collaboration among ASEAN HEIs would also surely be more pronounced in 2015, as such, a country with "valuable knowledge economy" regarding waste recovery and its marketing systems do not only help that particular country, but the whole ASEAN as well. ASEAN HEIs can start researches similar to the case presented in this paper in order to build related literature, as well as to prepare for a future community of ASEAN HEIs in 2015.

It has been stated in this paper that the case of recoverable materials in the three HEIs is high and that markets are present to recover these materials. However, related researches are highly needed to cross-validate facts as well as to formulate efficient plans for waste marketing and recovery. Waste analysis in HEIs is one important area of research as direct analysis and characterization of solid wastes provide data for waste reduction, reuse, recycling and composting opportunities (Thompson and Wilson; Thompson and van Bakel; as cited in
Smythe et al., 2010). Furthermore, determining the type and volume of generated wastes allow planners to design applicable waste treatment and disposal strategies, allocate necessary resources for managing solid wastes and implement appropriate SWM systems (Yousuf and Rahman, 2007; Nilanthi et al., 2007; 'What a Waste,' 2009).

Aside from waste characterization studies, data are still needed to solidify the case of marketing recoverable wastes in HEIs of the ASEAN region. The role of HEIs as institutions of research is emphasized, and that collaborative efforts are needed if the goal of a sustainable and green HEI would be achieved. It is imperative for researchers in ASEAN to boost SWM researches in HEIs to anticipate related problems in preparation for green HEIs in the ASEAN community by 2015 .

\section{Conclusions}

Colleges and universities can recover almost all of their wastes, as presented in the case of three HEIs in the Philippines. As such, ASEAN educational institutions should act the soonest time possible to efficiently manage their solid wastes. Recovering solid wastes not only reduce the quantity of wastes disposed in landfills, or promote a sense of environmental responsibility, but most importantly, it allows various educational institutions in ASEAN to grow and develop in a sustainable manner. HEI operation should be similar to how green industries operate, and HEIs in ASEAN can greatly reduce their waste output and create a waste-based economy. This mechanism not only promotes SD in ASEAN, but also contributes to achieving various sustainability-related goals worldwide.

\section{References}

Algie, J. (2010). Welcome to the EWasteland. South East Asia Globe. Retrieved from: http://www.seaglobe.com/Business/welcome-to-the-ewasteland.html. 
Alshuwaikhat, H. M. \& Abubakar, I. (2008). "An Integrated Approach to Achieving Campus Sustainability: Assessment of the Current Campus Environmental Management Practices," Journal of Cleaner Production, 16, 1777- 785.

Armijo De Vega, C., Ojeda Benítez, S. \& Ramírez Barreto, M. E. (2008). "Solid Waste Characterization and Recycling Potential for a University Campus," Waste Management, 28, S21 - S26.

Anacio, D. B. \& Gomez, R. Jr. (2011). 'Material Recovery Potential of Faculty Rooms and Cafeterias in Selected Private Higher Educational Institutions (Heis) of Baguio City,' Philippines. Unpublished Master's Thesis, Saint Louis University, Philippines.

ASEAN Secretariat, (July 2009). Implementing the Roadmap for an ASEAN Community 2015. ASEAN Annual Report 2008-2009.

Bandara, N. J., Hettiaratchi, J. P., Wirasinghe, S. C. \& Pilapiiya, S. (2007). "Relation of Waste Generation and Composition to Socio-economic Factors: A Case Study,"Environmental Monitoring and Assessment 135: 31 - 39.

Brown University (2004). Brown Recycling Program: Brown is Green. Retrieved June 2010 from: http://www.brown.edu/Departments/Bro wn_Is_Green/waste/recysum.html

Commission on Higher Education (CHED) (no date, n.d.). Information on Higher Education System. Retrieved from: http://202.57.63.198/chedwww/index.ph $\mathrm{p} / \mathrm{eng} /$ Information

Hashi, T. \& Mori, H. (2005). 'Networking International Recycling Zones in Asia,' Institute for Global Environmental Strategies (IGES). Policy Brief 1.
Iskandar, Ira (no date, n.d.) Higher Education in ASEAN - Working Paper. By Ira Iskandar, EU Centre Intern (Jul-Aug 2009) and NUS Political Science Honours Graduate. Retrieved March 2011 from: http://www.eucentre.sg/articles/21/down loads/WorkingPaper-HEAinASEAN-200908-01.pdf

Mbuligwe, S. E. (2002). "Institutional Solid Waste Management Practices in Developing Countries: A Case Study of Three Academia Institutions in Tanzania," Resources, Conservation and Recycling 35 (3), 131-146.

NSWMC (2009). National Solid Waste Management Commission Video and Ecological Solid Waste Management Kit. (DENR-EMB, CD-ROM, 2009 release).

OECD (2007). Higher Education for Sustainable Development. Final Report of International Action Research Project. Based on research carried out by Dr. Andy Johnston, seconded to the OECD from Forum for the Future. Retrieved 2011 from: www.oecd.org/dataoecd/55/4/45575516. pdf

Report and Declaration of the Presidents Conference (1990). Association of University Leaders for a Sustainable Future. Retrieved March 2012 from: http://www.ulsf.org/programs_talloires_re port.html

Smythe, D. P., Fredeen, A. L. \& Booth, A. L. (2010). "Reducing Solid Waste in Higher Education: The First Step towards 'Greening' a University Campus," Resources, Conservation, and Recycling, 54, 10071016.

UF (University of Florida) Sustainability Task Force (2002). Final Report. UF Office of Sustainability, USA. Retrieved from: www.sustainable.ufl.edu. 
UNESCO (2005). UN Decade of Education for Sustainable Development: 2005-2014, UNESCO-Education for Sustainable Development (www.unesco.org/education/desd).

What a Waste: Solid Waste Management in Asia (2009).World Bank Report. Retrieved: http://www.worldbank.org/urban/solid_ wm/erm/CWG\%20folder/uwp1.pdf

Yousuf, T. B. \& Rahman, M. (2007). "Monitoring Quantity and Characteristics of Municipal Solid Waste in Dhaka City," Environmental Monitoring and Assessment, 135, 3-11. 